\title{
The Interplay between VSO and Coordination in Two Types of Non-Degree Exclamatives*
}

\author{
Ana Maria Martins \\ Universidade de Lisboa (FLUL/CLUL) \\ anamartins@fl.ul.pt
}

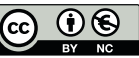

Received: August 1, 2013

Accepted: September 6, 2013

\begin{abstract}
This paper studies two types of indicative structures displaying subject-verb inversion which have received little attention in the literature on VS order in European Portuguese. Both types of structures involve coordination as a means to overtly express comparison/contrast, show a VSO pattern, and can be characterized as non-degree exclamatives. Whereas in one type (Type I) the post-verbal subject receives a contrastive focus reading, the other type (Type II) shows a less common pattern of subject-verb inversion, which does not involve focus on the subject nor verb-second syntax, but adds to the propositional content of the sentence an implicit comment conveying a speaker's attitude of disapproval towards the described state of affairs. It is proposed that the unifying factor behind the two types of VSO non-degree exclamatives is the presence of an evaluative feature in the $\mathrm{CP}$ field that triggers $\mathrm{V}$-to-C movement. Type I structures further involve movement of the subject to FocP and display V-to-C in both conjuncts of the coordinate structure. Type II structures do not involve focus-movement and V-to-C is restricted to the first member of the coordinate structure while the head of the structure itself (i.e. the coordinate conjunction) satisfies the evaluative feature of the second conjunct.
\end{abstract}

Keywords: non-degree exclamatives; VSO order; coordination; contrastive focus; evaluative meaning; European Portuguese.

\section{Table of Contents}

\section{Introduction}

2. Degree vs. non-degree exclamatives

3. Contrasting the two types of VOS non-degree exclamatives: $\mathrm{V}$-to-C and focus
4. VSO without focus: 'concessive' and 'adversative' non-degree exclamatives
5. Conclusion (VSO, coordination and exclamatives)
References

* Research for this paper was funded by FCT - Fundação para a Ciência e a Tecnologia within the project WOChWEL - Word Order and Word Order Change in Western European Languages (PTDC/CLE-LIN/121707/2010).

I am thankful to the editors of the current volume of CatJL and an anonymous reviewer, who in different ways contributed to this work. All shortcomings are, of course, my own responsibility. 


\section{Introduction}

The primary goal of this paper is to describe and analyze the syntax of two types of indicative structures displaying subject-verb inversion which have received little attention in the literature on VS order in European Portuguese. Both types of structures involve coordination as a means to overtly express comparison/contrast, show a VSO pattern, and can be characterized as non-degree exclamatives (Andueza 2011, Gutiérrez-Rexach and Andueza 2011). The account presented in the paper is intended to further the knowledge of the factors lying behind the marked VSO order in contemporary European Portuguese, and potentially in other languages. At the same time, it should add to the understanding of non-degree exclamatives, a less studied type of exclamative sentences (cf. Gutiérrez-Rexach 1996, Gutiérrez-Rexach and Andueza 2011, Andueza 2011, Villalba 2008, Castroviejo Miró 2008, Rett 2008, Ono 2006, Zanuttini and Portner 2003, Portner and Zanuttini 2000, among others). Whereas in one type of the exclamative structures to be discussed the post-verbal subject receives a contrastive focus reading (cf. Culicover and Winkler 2008), the other type of non-degree exclamatives shows a less common pattern of subject-verb inversion, which does not involve neither focus on the subject nor verb-second syntax. The two types of VSO non-degree exclamatives are exemplified in (1) to (10) below. All the sentences carry an implicit comment conveying a speaker's attitude of disapproval towards the described state of affairs. As will be shown at a later point in the paper, this implicit evaluative/emotive reaction disappears in the absence of subject-verb inversion (that is to say, SV sentences in contrast to their VS correlates do not add an emotive comment on top of the mere description of a state of affairs).

Type I structures (contrastive focus on the subject):

(1) Contas tu (a história) ou conto eu! (Não os dois ao mesmo tempo!) tell you the story or tell I not the two at-the same time 'Either it is you who tells the story or $\underline{I}$ do!' (It can't be both at the same time!)

(2) Não ajudaste tu a Maria, ajudei-a eu. not helped you the Maria helped-her I 'It wasn't you but I who helped Maria!'

(3) Ontem perdeu a Maria o casaco. Agora perdeu o João as luvas! yesterday lost the Maria the jacket now lost the João the gloves 'Yesterday it was Maria who lost her jacket. Now it was João who lost his gloves!' (Possible continuation: What's next?!)

(4) [A] Convidamos os meus pais para jantar? invite-1PL the my parents for dinner 'Should we invite my parents for dinner?'

[B] E fazes tu o jantar! / Cozinhas tu! and do-2SG you the dinner cook-2SG you 'You cook (dinner)!' (Implied: Not me!) 
Type II structures (no contrastive focus on the subject):

a) 'Concessive' meaning - the implied comment targets preferentially the second conjunct, but may target the first one as well; reordering of the conjuncts is not allowed, as it leads to ungrammaticality.

(5) Convidei eu a Maria para jantar e ela não apareceu! invited I the Maria for dinner and she not appeared 'I invited Maria for dinner and she didn't show up!' / 'Although I invited Maria for dinner, she didn't show up!'

(Implied: She should have shown up! or I shouldn't have invited her!)

(6) Leu o miúdo os livros todos e o professor dá-lhe esta nota! read the kid the books all and the professor gives-him this grade 'The kid read everything and the teacher gave him this (low) grade!' /'Although the kid read everything, the teacher gave him this (low) grade!' (Implied: The teacher should have given the kid a better grade! or There was no need for reading everything after all!)

(7) Estava eu tão feliz e tu tinhas de me dar essa notícia! was I so happy and you had of me give that news 'I was so happy but you had to bring that bad news!'

(Implied: You shouldn't have brought that bad news! or You can't see me happy!)

b) 'Adversative' meaning - the implied comment targets the first conjunct; reordering of the conjuncts and single-conjunct coordination ${ }^{1}$ are possible, as exemplified in (10). ${ }^{2}$

(8) Convidei eu toda a gente para jantar e afinal ainda não recebi invited I all the people for dinner and after all yet not received o ordenado! the salary 'I invited everybody for dinner and/but after all I haven't received my salary yet!'

(Implied: I shouldn't have invited everybody for dinner!)

(9) Não fomos nós ao jardim zoológico e esteve um dia de sol! not went we to-the garden zoological and was a day of sun 'We didn't go to the zoo and/but after all it was a sunny day!' (Implied: We should have gone to the zoo!)

1. See Zamparelli (2011).

2. Sentence (10b), however, sounds more natural than sentence (10c). Thus in spite of the availability of reordering of the conjuncts in sentences like (8) to (10), I will always refer to the clause displaying VSO order as 'the first conjunct'. 
(10) [Situation: the speaker is reading a poorly written paper by someone who wishes to be a writer]

a. E quer ela ser escritora! and wants she be writer 'How come she wants to be a writer?!'

b. Quer ela ser escritora e escreve desta maneira! wants she be writer and writes of-this manner 'She wants to be a writer and/but writes like this!'

c. Escreve desta maneira e quer ela ser escritora! writes of-this manner and wants she be writer 'She writes like this and/but wants to be a writer!'

Coordination (overt or covert), comparison/contrast and the VSO pattern are common features of the two types of structures illustrated above (i.e. Type I and Type II), which also share, to a certain extent, the possibility of omitting (but presupposing) one of the conjuncts of the coordinate structure (see (4) and (10) above). On the other hand, the examples make clear that the two relevant types of structures diverge in some important respects, namely:

(i) VS order surfaces in both conjuncts in Type I structures but only in the first conjunct in Type II structures;

(ii) Type I structures but not Type II structures involve contrastive focus on the subject (hence the subject in examples (1) to (4) can be clefted or associated with an exclusive/inclusive focus-marker as will be illustrated in section 3);

(iii) the two conjuncts of Type I structures can be juxtaposed (or may allow disjunctive coordination) while the two conjuncts of Type II structures are necessarily articulated by the coordinate conjunction $e$ 'and';

(iv) in Type II structures, but not in Type I, the VS order in the first conjunct introduces the counterexpectational flavor and 'anticipates' the contrast between the two propositions. ${ }^{3}$

It will be proposed in the paper that the unifying factor behind the two types of VSO non-degree exclamatives is the presence of an evaluative feature in the CP field that triggers verb movement to C (see Ambar 1992, 1999, Costa and Martins 2011, Ono 2006), as the application of standard tests for verb movement will demonstrate. On the other hand, there are two main differences between Type I and Type II structures: the former are derived with movement of the subject to FocP and display V-to-C in both conjuncts of the coordinate structure; the latter do not

3. I use here the terms 'concessive' and 'adversative' to identify each subtype of Type II exclamatives, instead of referring to them as subtype A and subtype B, for example. The 'concessive' subtype is easily paraphrased by a concessive sentence (see the examples (5)-(6) above) whereas the 'adversative' subtype is not. But I am in no way suggesting that the former should be analyzed as concessive sentences, at some grammatical level, and the latter as adversative sentences. In section 4 , the differences between the two subtypes are further discussed. 
involve focus-movement (of the subject) and $\mathrm{V}$-to-C is in general restricted to the first member of the coordinate structure while the head of the structure itself (i.e. the coordinate conjunction) satisfies the evaluative feature of the second conjunct. I will be adopting Johannessen's (1998) treatment of coordination as a Conjunction Phrase (CoP). The rationale of the account is as follows: the head of CoP inherits the evaluative feature of the first conjunct through Spec-Head agreement and can then license the evaluative feature of its complement (i.e. the second conjunct). This analysis allows us to derive the differences between structures like (5)-(7) and structures like (8)-(10). The contrast depends on whether each conjunct bears an evaluative feature of its own or only the conjunct displaying V-to-C does. In the former situation (i.e. examples (5) to (7)) reordering of the conjuncts is not possible because it would undo the right configuration to license the two independent evaluative features; if only the conjunct displaying $\mathrm{V}$-to-C bears the evaluative feature, however, reordering of the conjuncts is possible (but the implicit comment always falls on the conjunct bearing the evaluative feature, as illustrated above with examples (8) to (10)). Either way the head of the coordinate structure will inherit the evaluative feature and project it to $\mathrm{CoP}$.

The paper will deal with other properties of Type II structures, in particular: (i) the fact that they exclude the adversative conjunction mas 'but'; (ii) the fact that the coordinate sentences with a 'concessive' meaning are interpretatively equivalent (with some qualification) to subordinate structures displaying the connector para 'for', whereas the coordinate sentences with an 'adversative' meaning are interpretatively equivalent to subordinate structures displaying the connector quando 'when' (Valadas 2012).

The paper is organized in four further sections. Section 2 introduces the distinction between degree and non-degree exclamatives and shows why the sentences we will be dealing with throughout the paper qualify as non-degree exclamatives (not as declaratives). Section 3 provides empirical evidence supporting the proposal that VSO in the relevant types of structures is derived by V-to-C movement. It also demonstrates that while in type I non-degree exclamatives the subject receives a contrastive focus interpretation, this is not the case in type II exclamatives. A structural analysis is suggested at this point for type I non-degree exclamatives. Section 4 focuses on type II non-degree exclamatives, elucidates the interpretative contrast between the VSO sentences and their SVO correlates, and offers an integrated analysis that allows us to derive the similarities and differences between the structures displaying an 'adversative' meaning and the structures displaying a 'concessive' meaning. It also considers the exclusion of the adversative conjunction mas 'but' from type II structures and briefly comments on the relation between the coordinate structures expressing 'concessive'/'adversative' meanings and particular kinds of subordinate structures apparently expressing similar meanings. Section 5 concludes the paper with a summary and a brief reference to possible connections between the VSO structures discussed in the paper and other VSO sentences found in European Portuguese that share with the former either a contrastive focus interpretation for the subject or an evaluative/emotive component. 


\section{Degree vs. non-degree exclamatives}

Exclamatives differ from other types of sentences by their expressive semantic content. By uttering an exclamative sentence the speaker expresses an emotive attitude towards the content of his/her utterance. As Castroviejo Miró (2008: 58) puts it: «The speaker who makes an assertion wants to provide information and the speaker who utters an exclamative wants to express him/herself»». ${ }^{4}$ The speaker may express wonder, admiration, amazement, surprise, joy, satisfaction, annoyance or criticism, among other emotive attitudes. The type of exclamative sentences that we will be discussing throughout the paper always expresses criticism, in the form of disapproval or annoyance. A clear test to demonstrate this specific restriction on the set of possible speaker's attitudes can be constructed by adding an interjection at the left edge of the exclamative sentence. Although interjections and exclamative sentences are, in central ways, similar objects and fit well together (see Castroviejo Miró 2008), the particular type of exclamative sentences in which we are interested exclude interjections that express a positive emotive reaction. In European Portuguese, this is the case of the interjections uau or ena (see (11)). As exemplified below, when these positively marked interjections precede a coordinate VSO exclamative sentence (be it of Type I or Type II) the result is an ungrammatical structure (see (12)). On the other hand, a negatively marked interjection like bolas or porra is perfectly compatible with the same exclamative sentences (see (13)). ${ }^{5}$

(11) a. Uau!/Ena! Que linda casa! INTERJ what beautiful house 'What a beautiful house!'

b. Uau!/Ena! Ele é mesmo bonito! INTERJ he is really beautiful 'How beautiful he is!'

4. Considering the propositional content of exclamatives, Castroviejo Miró (2008: 85) elucidates: "Moreover, in the case of exclamatives, there is a descriptive content that is not introduced as an assertion, either. Instead, it has been proposed that it spells out the cause of the expressive meaning and, hence, it is another content that is treated as noncontroversial».

5. As noted by an anonymous reviewer, the incompatibility between the exclamative structures under discussion and positive interjections seems to indicate that the evaluative feature of exclamatives may have a positive or negative value. In other words: either the feature is finer grained or there is a second feature involved. This is a very interesting point but I will not be able to elaborate on it at present, as it would require going into a detailed typology of exclamative sentences. 
(12) a. *Uau!/Ena! Contas tu (a história) ou conto eu! (Não os dois INTERJ tell you the story or tell I not the two ao mesmo tempo!) at-the same time 'Either it is you who tells the story or I do!' (It can't be both at the same time!)

b. *Uau!/Ena! Não fomos nós ao jardim zoológico e afinal INTERJ not went we to-the garden zoological and after all esteve um dia de sol! was a day of sun 'We didn't go to the zoo and after all it was a sunny day!'

(13) a. Porra! Contas tu (a história) ou conto eu! (Não os dois ao INTERJ tell you the story or tell I not the two at-the mesmo tempo!)

same time

'Either it is you who tells the story or I do!' (It can't be both at the same time!)

b. Bolas! Não fomos nós ao jardim zoológico e afinal esteve INTERJ not went we to-the garden zoological and after all was um dia de sol! a day of sun 'We didn't go to the zoo and after all it was a sunny day!'

Exclamative sentences have been considered to display another distinctive property, namely factivity (Grimshaw 1979, Portner and Zanuttini 2000, Zanuttini and Portner 2003). Exclamative constructions are factive because they presuppose the truth of the proposition they denote. Moreover, the propositional content of exclamatives is typically presupposed by both speaker and addressee. For example, in (14) below, the exclamative sentence by itself cannot answer the question posed by [A] (one of the tests for factivity used by Grimshaw 1979), but the exclamative sentence turns out to be just fine if it is preceded by a negative answer to the polarity question (see the contrast between (a) and (b)). So the exclamative sentence in (14) is only felicitous if the fact that 'Maria didn't show up for the dinner she had been invited to' is already known by speaker and addressee. ${ }^{6}$

6. In this particular case, the VSO exclamative sentences studied in the present paper do not behave as predicted by Gutiérrez-Rexach and Andueza (2011: 292) as for the distinction between degree and non-degree exclamatives:

«The main difference between propositional [i.e. non-degree] exclamatives and degree exclamatives relates to their respective presuppositions. Whereas in the latter the content is part of the common ground, that is, it is presupposed by the speaker and the addressee; in the former the content is presupposed only by the speaker, and the addressee has to accommodate the new information». 
$\begin{array}{rlll}\text { (14) }[\mathrm{A}] \mathrm{A} & \text { Maria veio ao jantar? } \\ \text { the } & \text { Maria came to-the dinner }\end{array}$

'Did Maria attend the dinner?'

[B] a. \#Convidei-a eu pra jantar e ela não apareceu! invited-her I for dinner and she not appeared

b. Não. Convidei-a eu pra jantar e ela não apareceu!

No invited-her I for dinner and she not appeared

'No, she didn't. I invited her for dinner and she didn't show up!'

This is further illustrated by (15), where the positive answer can be omitted because it is implied by the emotive reaction expressed by the exclamative sentence. ${ }^{7}$

(15) [A] Pá, inda tás chateada por a Maria não ter vindo ao jantar? man still are upset for the Maria not have come to-the dinner 'Man, are you still upset because Maria didn't show up for the dinner?'

[B] (Estou.) Convidei-a eu pra jantar e ela não veio! am invited-her I for dinner and she not came

'I am. I invited her for dinner and she didn't show up!'

The literature on exclamatives has mostly focused on wh-exclamatives and other exclamative constructions involving a gradable property (see the informative overview provided by Villalba 2008). Here we will follow Gutiérrez-Rexach and Andueza (2011) on the assumption that exclamatives are not uniform and «some of them cannot be interpreted as degree constructions» (Gutiérrez-Rexach and Andueza 2011: 287; cf. Andueza 2011). In the remainder of this section we will use some of the tests devised by Gutiérrez-Rexach and Andueza (2011) in order to distinguish between degree and non-degree exclamatives and will show that the coordinate VSO exclamatives investigated in this paper belong to the second type (but see footnote 6 above).

Degree and non-degree exclamatives behave differently in the way they interact with negation. The presence of ordinary negation is severely restricted in degree exclamatives (see Villalba (2004, 2008), and González Rodríguez (2009), who shows that negation is only allowed in wh-exclamatives when it has narrow scope with

7. The kind of factivity that underlies exclamatives is certainly related to a characteristic feature of the exclamative coordinate structures discussed in this paper, namely the requirement that the inverted subject be definite (Valadas 2012). But I will not be able to pursue this issue here. Cf. Melvold (1991), Zanuttini and Portner (2003), Villalba (2008). The same requirement holds for the type of exclamatives involving quantifier fronting studied by Raposo (1995, 2000), Ambar (1999) and Costa and Martins (2011) (although subject-verb inversion is optional in this case). The relevant contrast is illustrated below.

(i) a. Muito vinho bebeu o capitão!

much wine drank the captain

b. *Muito vinho bebeu um marinheiro!

much wine drank a sailor 
respect to the wh-phrase). Non-degree exclamatives, on the other hand, do not seem to impose limitations on the occurrence of ordinary negation. Conversely, and extending the observations by Gutiérrez-Rexach and Andueza (2011), expletive negation is licensed by different types of degree exclamatives but not by non-degree exclamatives. Sentence (16) is an example of a degree exclamative that allows ordinary negation. In such cases there is ambiguity between a regular and an expletive reading for the negation marker (the former reading being more salient than the latter).

(16) Quantos livros ele não leu!

how many books he not read

'How many/The books he has not read!' (regular negation reading)

'How many/The books he read!' (expletive negation reading)

Importantly, such ambiguity is not found in the VSO exclamative sentences discussed in this paper. They easily allow negation but totally exclude an 'expletive negation' reading, as exemplified in (17) and (18), which aligns them with non-degree exclamatives.

(17) [A] Convidamos os meus pais para jantar? invite-1PL the my parents for dinner

'Should we invite my parents for dinner?'

[B] Não faço eu o jantar! not do I the dinner

'It won't be me who cooks dinner!' (Implied: You do it!)

*'I will cook dinner. / I will be the one cooking dinner.'

(impossible reading)

(18) a. Não convidei eu a Maria para jantar e ela apareceu! not invited I the Maria for dinner and she appeared 'I didn't invite Maria for dinner and she did show up!'

b. *Não convidei eu a Maria para jantar e ela não apareceu! not invited I the Maria for dinner and she not appeared *'I invited Maria for dinner and she did (not) show up!' (impossible readings)

According to Gutiérrez-Rexach and Andueza (2011), another characteristic feature of degree exclamatives is their incompatibility with comparative structures. This is not the case of the non-degree exclamatives under discussion, as shown in (19) and (20) respectively for Type II and Type I coordinate VSO exclamatives. ${ }^{8}$

8. A variant of example (19) displaying a comparative structure in both conjuncts is also a grammatical option:

(i) Mimo-o eu mais do que ao irmão e ele acha que eu gosto mais do pamper-him I more than to-the brother and he thinks that I like-1sG more of-the irmão do que dele! brother than of-him 'I pamper him more than his brother and he claims that I like his brother better than him!' 
(19) Mimo-o eu mais do que ao irmão e ele acha que não pamper-him I more than to-the brother and he thinks that not gosto dele!

like-1SG of-him

'I pamper him more than his brother and he claims that I don't like him!'

(20) [A] Como é que vamos dividir a tarefa ao meio? how is that go-1PL split the task to-the half 'How should we split the task in half?'

[B] Não há como dividir ao meio. Ou fazes tu mais do que eu not there is how split to-the half or do you more than I ou faço eu mais do que tu! or do I more than you

'There is no way we can split the task in half. Either you will do more than me or I will do more than you.'

Degree exclamatives comment on properties and express the speaker's emotive attitude towards their amount, extent or intensity; non-degree exclamatives comment upon a fact (or state of affairs) and express the speaker's emotive attitude towards its unexpectedness. As Gutiérrex Rexach and Andueza (2011: 294) phrase it: «the content of an exclamative construction can be either a fact or a property, and the discourse contribution is the speaker's emotional attitude towards it. The difference between what we have called propositional [i.e. non-degree] exclamatives and degree exclamatives relies in the trigger of the associated emotional attitude: an unexpected fact, in the case of propositional exclamatives, and the high or extreme degree of a property, in the case of degree exclamatives».

The implicit comment carried by coordinate VSO exclamative sentences always targets a fact or state of affairs, not a gradable property. Type II exclamatives, in particular, make especially clear that at their core is the comparison between two facts (or state of affairs) from which the unexpectedness effect results. The parallelism provided by the coordinate structure permits the explicit display of the two terms being compared. The result is only grammatical if a counterexpectational relation emerges. This is exemplified by the coordinate sentences in (21) and (22) below. If the propositional content of the second conjunct is unexpected relative to the propositional content of the first conjunct, the sentences are perfectly grammatical (examples (a)); otherwise, they are infelicitous or ungrammatical (examples (b)) because there is no trigger/cause for the speaker's emotional attitude. 
(21) [Situation: I don't like fish but I know that my guest loves fish.]

a. Fiz eu peixe para o jantar e ele não comeu! did I fish for the dinner and he not ate 'I cooked fish for dinner and he did not eat!'

b. \#Fiz eu peixe para o jantar e ele comeu! ${ }^{9}$ did I fish for the dinner and he ate 'I cooked fish for dinner and he did eat!'

(22) a. Comprei-lhe eu três camisas e ele só veste a azul! bought-him I three shirts and he only wears the blue 'I bought him three shirts and he only wears the blue one!'

b. *Comprei-lhe eu três camisas e ele veste todas! bought-him I three shirts and he wears all 'I bought him three shirts and he wears them all!'

\section{Contrasting the two types of VOS non-degree exclamatives: V-to-C and focus}

In this section, I will first resort to standard tests provided by adverb placement in order to show that V-to-C movement is a characteristic property of both Type I and Type II exclamatives. I will leave for the next section the explanation for why $\mathrm{V}$-to-C only occurs in the first conjunct in Type II structures. I will then proceed to demonstrate that in Type I but not in Type II sentences the subject bears a contrastive focus interpretation. Then I will suggest a structural analysis for Type I exclamatives. I will account for Type II exclamatives in section 4.

\subsection{Subject inversion and $V$-to-C}

Adverb placement in EP offers clear evidence that in Type II exclamatives there is verb movement to $\mathrm{C}$.

First, -ly adverbs like frequentemente 'frequently' may regularly appear in post-verbal position or preverbal position, in between the subject and the verb, in regular declarative sentences in European Portuguese, adjoining respectively to VP or TP (Costa 1998), as exemplified in (23).

(23) a. Eu convido frequentemente a Maria mas ela nunca aparece. I invite frequently the Maria but she never appears 'I often invite Maria but she never shows up.'

b. Eu frequentemente convido a Maria mas ela nunca aparece.

c. Frequentemente eu convido a Maria mas ela nunca aparece.

9. The sentence would be fully acceptable if knowing that my guest is not a fish eater, I had cooked fish with the mischievous purpose that he would not eat dinner. 
In Type II exclamatives, however, there is only one position available for the adverb, namely after the verb and the post-verbal subject, as exemplified in (24).

(24) a. Convido eu frequentemente a Maria e ela nunca aparece! invite I frequently the Maria and she never appears 'I often invite Maria and/but she never shows up!'

b. *Convido frequentemente eu a Maria e ela nunca aparece!

c. *Frequentemente convido eu Maria e ela nunca aparece!

Assuming that the verb is in $\mathrm{C}$ in the relevant exclamative sentences (whereas it does not move beyond $\mathrm{T}$ in declaratives like (23)), we can explain why the adverb must follow the verb, independently of whether the adverb is adjoined to VP or TP. Besides, the ungrammaticality of (24b) demonstrates that the post-verbal subject of Type II exclamatives does not stay inside VP, otherwise the adverb adjoined to TP would be able to intervene between the verb and the post-verbal subject. Finally, the ungrammaticality of (24c) indicates that in Type II exclamatives topicalization of the adverb is not allowed. Similar facts can be observed with the temporal adverb ontem 'yesterday', as illustrated in (25)-(26).

(25) a. Eu convidei-a ontem pra jantar mas ela não apareceu. I invited-her yesterday for dinner but she not appeared 'Yesterday I invited her for dinner but she didn't show up.'

b. Eu ontem convidei-a pra jantar mas ela não apareceu.

c. Ontem eu convidei-a pra jantar mas ela não apareceu.

(26) a. Convidei-a eu ontem pra jantar e ela não apareceu! invited-her I yesterday for dinner and she not appeared 'I invited her for dinner yesterday and/but she did not show up!'

b. *Convidei-a ontem eu pra jantar e ela não apareceu!

c. *Ontem convidei-a eu pra jantar e ela não apareceu!

Second, the EP adverb bem 'well' is basically a manner adverb that adjoins to VP (Costa 1998), but it may occur in a structurally higher position, in which case it is devoid of the manner interpretation displaying instead a modal/emphatic import, as exemplified in (27). ${ }^{10}$

10. I do not have a specific analysis to offer for this structurally higher bem in European Portuguese. But see Hernanz (2010) and Batllori and Hernanz (2013) for Spanish bien and Catalan bé/ben, as a similar contrast between a manner and an assertive interpretation for the adverb arises in these other languages. According to the referred authors, assertive bien/bé is a polarity word that merges in PolP and then moves to FocusP (in the sentential left-periphery). 
(27) a. O Pedro falou bem.

the Pedro spoke well

'Pedro spoke well.'

b. Bem disse o Pedro que era verdade.

well said the Pedro that was true

'Pedro was right in saying that it was true.' / 'Pedro actually said that it was true.'

c. Ele bem sabe que é verdade.

he well knows that is true

'He definitely knows that it is true.' / 'I'm sure that he knows that it is true.'

As a manner adverb it necessarily occurs after the post-verbal subject in Type II exclamatives, showing the same pattern as the adverbs frequentemente and ontem, as shown in (28).

(28) a. Rego eu bem as plantas e não se desenvolvem! water I well the plants and not REFL grow

'Although I water the plants well, they don't grow properly!'

b. *Rego bem eu as plantas e não se desenvolvem!

Significantly, the modal/emphatic bem is incompatible with Type II exclamatives, which indicates that either it induces an intervention effect blocking V-to-C or verb movement to $\mathrm{C}$ undoes the structural configuration that enables the modal/ emphatic interpretation of bem. The examples in (29) show that in a SV declarative both the manner and the modal/emphatic readings of bem are available (see (29a,b)) but in the relevant VS exclamative the modal/emphatic reading is not permitted (see (29c)). This is further evidenced by (30).

(29) a. Eu rego (bem) as plantas (bem) mas não se desenvolvem.

I water well the plants well but not REFL grow

'I water the plants well but they don't grow properly.'

b. Eu bem rego as plantas mas não se desenvolvem.

I well water the plants but not REFL grow

'I do/really water the plants but they don't grow properly.'

c. *Bem rego eu as plantas e não se desenvolvem!

(30) a. (Eu) bem (eu) avisei o João mas ele não quis ouvir.

I well I warned the João but he not wanted listen

'I did warn João but he didn't listen to me.'

b. *Bem avisei eu o João e ele não quis ouvir! well warned I the João and he not wanted listen

c. Avisei eu o João e ele não quis ouvir! warned I the João and he not wanted listen 'I warned João but he didn't listen to me!' 
If we now turn our attention to Type I exclamatives, we obtain the same kind of patterns of adverb placement. On the one hand, -ly adverbs that usually can surface between the subject and the verb in preverbal position or instead in post-verbal position are restricted in Type I VSO exclamatives to the post-subject position, as exemplified in (31).

(31) a. Contas tu rapidamente a história ou conto-a eu! tell you rapidly the story or tell-it I 'Either you tell the story at once or I do!'

b. *?Contas rapidamente tu a história ou conto-a eu!

c. *?Rapidamente contas tu a história ou conto-a eu!

On the other hand, the adverb bem can appear further to the right, in clause-final position, if the object undergoes short scrambling (compare (32a), displaying object scrambling, with (32b), and see Costa 1998) but crucially cannot appear to the left of the subject (see $(32 \mathrm{c}, \mathrm{d})$ ). Since the adverb bem is a signpost for the VP border, the word order of sentences (32a-c) demonstrates that VS in Type I exclamatives does not result from moving the verb to $T$ while the subject would stay in its base position. Actually, if this was the case, we would expect the order VOS to be allowed in Type I exclamatives, against the facts.

(32) a. Contas tu a história bem ou conto(-a) eu (bem)! tell you the story well or tell-it I well 'Either you tell the story properly or I do!'

b. ?Contas tu bem a história ou conto(-a) eu (bem)!

c. *Contas bem tu a história ou conto bem eu!

d. *Contas bem a história tu ou conto bem eu!

\subsection{Subject inversion and focus}

Adverb placement aligns Type I with Type II exclamatives and supports the hypothesis that both display V-to-C. Although the two types of exclamatives also share subject-verb inversion (as expected if the verb moves to the CP field), they clearly diverge with respect to the interpretation of the subject DP. This is revealed by the smooth availability of clefting of the subject DP in sentences that paraphrase Type I exclamatives, as opposed to Type II exclamatives, indicating that only the subject of Type I exclamatives is interpreted as contrastive focus. Observe the grammaticality of the sentences in (33) in contrast to the ungrammaticality of the sentences in (34)-(35) when clefting is applied to test the interpretative status of the subject. 
(33) a. Ou és tu que contas a história ou sou eu! Não os dois ao or is you that tell the story or is I not the two at-the mesmo tempo.

same time

'Either it is you who tells the story or it is me! Not both at the same time.'

b. Ontem foi a Maria que perdeu o casaco, hoje foi o João yesterday was the Maria that lost the jacket today was the João que perdeu as luvas! Não ganho para os vestir.

that lost the gloves not earn for them dress

'Yesterday it was Maria who lost her jacket, today it was João who lost his gloves. I don't earn enough to dress them!'

(34) a. *Era eu que estava tão feliz e (eras) tu (que) tinhas de me was I that was so happy and was you that had of me dar essa notícia!

give that news

b. *Eu é que estava tão feliz e tu (é que) tinhas de me dar essa I is that was so happy and you is that had of me give that notícia!

news

'I was so happy but you had to bring that (bad) news!'

(35) a. *Fomos nós que não fomos ao jardim zoológico e esteve um were we that not went to-the garden zoological and was a dia de sol!

day of sun

b. *Nós é que não fomos ao jardim zoológico e esteve um dia we is that not went to-the garden zoological and was a day de sol!

of sun

'We didn't go to the zoo and/but after all it was a sunny day!'

The focus interpretation of the subject in Type I exclamatives is also revealed by its felicitous combination with exclusive or inclusive focus markers (like só 'only', sempre 'always', também 'also'), as exemplified in (36a-c). Importantly, the subject does not naturally appear in the sentence final position that is characteristic of narrow information focus in European Portuguese, as shown in (36d-g). This constitutes clear evidence that we are dealing here with a different kind of focus, which relates to a different structural configuration. In the next section we will suggest that in Type I exclamatives the subject moves to a low Spec,FocP position within the $\mathrm{CP}$ field while the verb moves past it. 
(36) A: Vou convidar os meus pais para passarem uma semana connosco. go-1SG invite the my parents for spend one week with-us 'I'm going to invite my parents to spend one week with us.'

B: a. E fazes [só tu] o jantar! and do only you the dinner

b. E fazes [sempre tu] o jantar! and do always you the dinner 'And it is you who cooks dinner every day!'

c. E fazes [também tu] o jantar! and do also you the dinner 'So you will also cook dinner!'

d. E cozinhas $t u$ todos os dias! and cook you all the days 'And you cook dinner every day!'

e. *E cozinhas todos os dias $t u$ !

f. E fazes $t u$ todos os dias o jantar! and do you all the days the dinner 'And you cook dinner every day!'

g. *E fazes todos os dias o jantar $t u$ !

The VSO nature of the exclamative sentences under discussion is further attested by (37), which sets these sentences apart from VOS declaratives where the subject is narrow information focus. ${ }^{11}$

(37) a. Não pagou ele /o João o jantar, paguei eu! not paid he the João the dinner paid I 'He/João did not pay the dinner, I did!'

b. *?Não pagou o jantar ele / o João, paguei eu!

c. Ou the compra $o$ pai o passe ou levo-o eu à escola! or him buy the father the pass or take-him I to-the school 'Either his father pays for his monthly bus pass or I will take him to school myself'

d. *?Ou lhe compra o passe o pai ou levo-o à escola eu!

11. Although the grammaticality contrasts are somehow weaker when the subject is not a pronoun, they still hold, as shown below.

(i) a. E cozinha a tua mãe todos os dias! and cook the your mother all the days 'And your mother cooks every day!'

b. ??E cozinha todos os dias a tua mãe!

c. E faz o teu pai todos os dias o jantar! and do the your father all the days the dinner 'And your father cooks dinner every day!'

d. *?E faz todos os dias o jantar o teu pai! 


\subsection{The syntax of Type I VSO exclamatives}

It is not my aim in this paper to propose a syntactic analysis for exclamative sentences in general (see Villalba 2008 for an overview) or even a full syntactic analysis for the type of exclamative sentences discussed here. But I will put forward the hypothesis that exclamative sentences always include an evaluative feature in $\mathrm{C}$. Then I will show how this hypothesis works to account for some central properties of the particular kind of exclamative sentences studied in the current paper. I will refer to the relevant functional head that carries the evaluative feature as $\mathrm{C}_{[+ \text {eval] }}$, but could as well name it Evaluative (Ambar 1999) or Mood (Ono 2006). ${ }^{12}$ For Type I exclamatives (but not for Type II) I will take the subject to move to a low FocP position in the $\mathrm{CP}$ field. Coordination offers the appropriate configuration to support the contrastive (or listing) interpretation of the subject. I will be assuming the asymmetric syntax for coordination where the coordinator is the head and takes the first conjunct as its specifier and the second as its complement (see Progovac (1998a,b) for a thorough overview; cf. Camacho 2003). Moreover, I specifically adopt Johannessen's (1998) analysis of coordination, which allows the evaluative feature of the first conjunct, the specifier of the Conjunction Phrase (CoP), to percolate up to CoP, by Spec-Head agreement. This is common to both types of exclamatives (although in Type II exclamatives the role of coordination is more central, as will be explained in section 4). The syntactic structure of a single-conjunct Type I exclamative is roughly as indicated in (38) below. ${ }^{13}$ Whenever CoP has its specifier realized in Type I exclamatives, the two conjuncts will display a parallel syntactic structure and the head of $\mathrm{CoP}$ will inherit the evaluative feature by Spec-Head agreement. By hypothesis, when the specifier is missing (like in (38)), the head of the structure is independently associated with an evaluative feature, which must be licensed by the discourse context. Note that (38) requires a linguistic antecedent and would be ungrammatical if uttered out of the appropriate linguistic context (see (4) above).

$$
\begin{aligned}
& {[\mathrm{CoP}[+\mathrm{eval}]][\mathrm{CP}[+\mathrm{eval}]} \\
& \text { and } \left.\text { fazes }_{\mathrm{i}}\left[\mathrm{FocP}_{\mathrm{FP}} t u_{\mathrm{j}}\left[\mathrm{IP}_{\mathrm{i}} \mathrm{t}_{\mathrm{j}} o \text { jantar }\right]\right]\right] \\
& \text { do you the dinner } \\
& \text { 'You cook dinner! (Implied: Not me!)' }
\end{aligned}
$$

In independent work on the syntax of unambiguous metalinguistic negation (MN) markers in European Portuguese (Martins, forthcoming), I have shown that the MN marker agora (literally, 'now'), like unambiguous MN markers in general,

12. It is not my purpose in the current paper to undertake a cartographic approach to the CP space. So, I use CP as cover term for what might eventually be different categories within the CP domain. Note, nonetheless, that FocP and TopP were around in the syntactic literature way before Rizzi's cartographic approach came into play. So I will use FocP without being cartographic or incoherent.

13. Cf. Zamparelli (2011: 1723): «The most extreme case of asymmetric coordination is of course SINGLE-CONJUNCT COORDINATION, which is restricted to sentential material (...). Since the missing coordinand is always initial this structure is strong evidence for an asymmetric structure for coordination, but its formal semantics and its discourse properties are largely unexplored». 
realizes a functional position in the $\mathrm{CP}$ space. Besides, the $\mathrm{MN}$ marker agora, which usually surfaces in sentence-final position, admits overt material to its right if some constituent is moved to a low FocP position in the CP domain, as exemplified in (39). ${ }^{14}$

(39) a. [A] O João deu um carro à Maria. the João gave a car to-the Maria. 'John gave Mary a car.'

b. [B] O João deu agora um carro à Maria. the João gave MN a car to-the Maria 'Like hell/no way João gave Mary a car.'

b'. $\left[_{\mathrm{TopP}}\left[{ }_{\Sigma \mathrm{P}} \mathrm{O} \text { João deu } \mathrm{f}_{\mathrm{VP}} \text { tm earro à Maria }\right]_{\mathrm{m}}\right]_{\mathrm{k}}\left[_{\mathrm{Top}},\left[_{\mathrm{CP}}\right.\right.$ agora $\left[_{\mathrm{C}},\left[_{\mathrm{FocP}}\right.\right.$

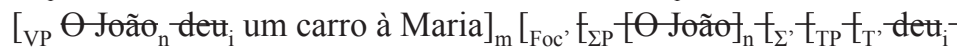

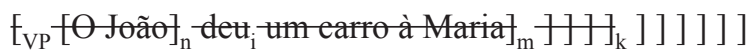

We may thus test whether the post-verbal subject of Type I exclamatives is allowed to follow the MN marker agora, as we would expect if it occupies the same structural position as the material surfacing to the right of the MN marker, namely Spec, FocP. As (40) illustrates, this is in fact the case. Sentence (40) also shows that differently from what adverb placement may suggest (see sections 3.1 and 3.2 above), the subject of Type I exclamatives does not have to be adjacent to the verb. Crucially it is an element belonging to the $\mathrm{CP}$ space (i.e. the MN marker agora) that can intervene between the verb and the subject. ${ }^{15}$

(40) a. Não contas tu (a história), conto eu! not tell you the story tell I! 'It won't be you but me who will tell the story!'

b. Não conto agora eu (e contas tu)! not tell MN I and tell you 'Like hell, it's not me (but you) who will tell it!'

14. The different steps of the derivation are elucidated below (see Martins, forthcoming):

STEP 1: Remnant movement of the VP to Spec,FocP

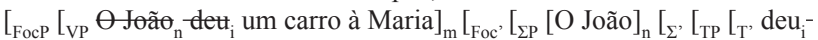

$\mathrm{E}_{\mathrm{VP}}\left[\Theta\right.$ João $_{\mathrm{n}}$-dett

STEP 2: External merge of agora in Spec,CP

$\left[_{\mathrm{CP}}\right.$ agora $\left[_{\mathrm{C}},\left[_{\mathrm{FocP}}\left[{ }_{\mathrm{VP}} \Theta \text { João }_{\mathrm{n}} \text { tett }_{\mathrm{i}} \text { um carro à Maria }\right]_{\mathrm{m}}\left[_{\mathrm{Foc}},\left[_{\Sigma \mathrm{P}}[\mathrm{O} \text { João }]_{\mathrm{n}}\left[{ }_{\Sigma}\right.\right.\right.\right.\right.$,

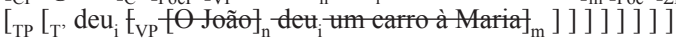

STEP3: Remnant movement of $\Sigma$ P to Spec,TopP

$\left[_{\text {TopP }}\left[{ }_{\Sigma P} \mathrm{O}\right.\right.$ João deu $\mathrm{E}_{\mathrm{VP}}$

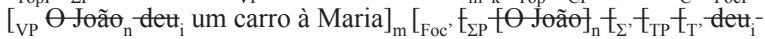

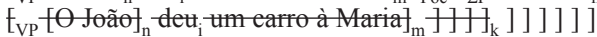

15. There is some difference between the derivation of (39) and the derivation of (40)-[B]b), since in the latter there is verb movement to $\mathrm{C}$, but this is irrelevant for our current purposes. Sentence (40)-[B]b) makes clear that the CP space may contain more structure than shown in (38). 


\section{VSO without focus: 'concessive' and 'adversative' non-degree exclamatives}

The unifying factors behind the two types of non-degree exclamatives under discussion are coordination and the presence of an evaluative feature in the $\mathrm{CP}$ field that triggers verb movement to C, deriving the VSO order. But in Type II structures, differently from Type I, verb movement to $\mathrm{C}$ is restricted to the first member of the coordinate structure, so only the first conjunct displays subject-verb inversion. Under the hypothesis that an evaluative feature might be independently associated with the second conjunct as well, it will be the head of the coordinate structure itself (i.e. the coordinate conjunction) that satisfies $\mathrm{C}_{[+ \text {eval] }}$ and dispenses with $\mathrm{V}$-to-C. Adopting Johannessen's (1998) theory of coordination, the rationale of the account is as follows. The head of CoP inherits the evaluative feature of the first conjunct through Spec-Head agreement and can then license the evaluative feature of its complement, whenever the second conjunct bears its own evaluative feature. ${ }^{16}$ In any case, the head of the coordinate structure will inherit the evaluative feature of its specifier and project it to CoP. A sketchy representation of the syntactic structure of Type II exclamatives is given below (cf. section 1 for a description of the two variants). The main difference between (41) and (42) is the existence or not of an evaluative feature in the complement of $\mathrm{Co}$, which in turn has consequences with respect to mobility of the second conjunct, availability of single-conjunct coordination, and interpretation, as will be clarified farther on. The proposed analysis allows us to derive the similarities and contrasts between structures like (41) and (42). The contrasts depend on whether each conjunct bears an evaluative feature of its own or only the conjunct displaying subject-verb inversion does.

Type II - 'concessive'

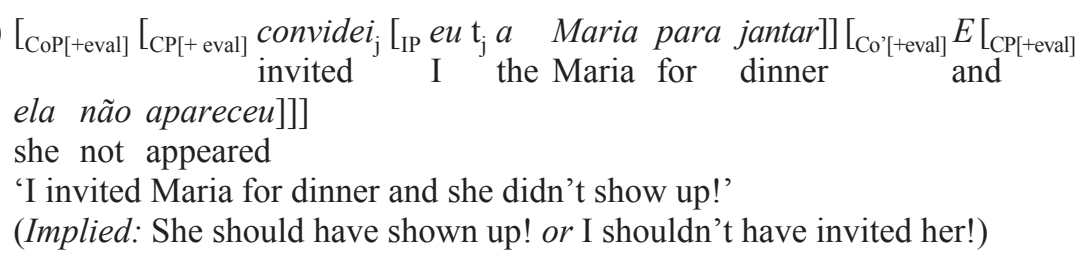

16. I do not have an answer at this point for why in Type I exclamatives both conjuncts display VS order (in contrast to Type II exclamatives), but two hypotheses come to mind. Either feature inheritance by Spec-Head agreement is not extensive to all types of coordinate structures (the two conjuncts of Type I exclamatives are usually not linked by the coordinator $e$ 'and') or subject-verb inversion in Type I exclamatives is not only a consequence of $\mathrm{C}_{[+ \text {eval] }}$ but is in some way related with the projection of FocP. The data displayed below seem to support this idea because in sentence (i) subject-verb inversion surfaces in the two conjuncts of a non-exclamative coordinate structure.

(i) Amanhã escrevo aos organizadores. Há uns tempos ficaram de me dizer se tomorrow write-1SG to-the organizers there is some time stayed of me tell if comprava eu o bilhete ou compravam eles. bought I the ticket or bought them 'Tomorrow I will write to the conference organizers. They were supposed to let me know whether I will buy the ticket or they will.' 
Type II - 'adversative'

$$
\begin{aligned}
& {\left[{ } _ { \mathrm { CoP } [ + \mathrm { eval } } \left[_ { \mathrm { CP } [ + \text { eval } } n \tilde { a } o \text { fomos } _ { \mathrm { j } } [ { } _ { \mathrm { IP } } \text { nós } \mathrm { t } _ { \mathrm { j } } \text { ao jardim zoológico } ] \left[_{\mathrm{Co}}, E\right.\right.\right.} \\
& \text { [ }{ }_{\mathrm{CP}} \text { está um dia de sol]]] } \\
& \text { is a day of sun } \\
& \text { 'We didn't go to the zoo and after all it's a sunny day!' } \\
& \text { (Implied: We should have gone to the zoo!) }
\end{aligned}
$$

The implicit comment carried by 'concessive' exclamatives may target any of the conjuncts of the coordinate structure because each of them is independently associated with an evaluative feature. On the other hand, in 'adversative' exclamatives only the first conjunct bears the evaluative feature and so can be the object of the speaker's implicit comment.

Reordering of the conjuncts is impossible in (41) above because the evaluative feature of the SV clause (i.e. ela não apareceu) would not be licensed, neither by $\mathrm{V}$-to-C nor through the head-complement relation (thus (43a) below is ungrammatical). Sentence (42) above, on the other hand, allows reordering of the conjuncts, since there is no evaluative feature in the second conjunct needing to be licensed. Nevertheless, the operation results in a less cohesive and natural sequence (see (43b) below). This fact can be accounted for if we take the reordered sequence to be actually composed by two sentences, namely an SV independent sentence and a single-conjunct coordinate structure containing the VS clause (cf. (38) above). This is why 'adversative' exclamatives, in contrast to 'concessive' exclamatives, allow single-conjunct coordination, as illustrated in (44). So, to be precise, there is never reordering of the conjuncts in Type II exclamatives. The difference between the 'concessive' and the 'adversative' kind is that only the latter is compatible with single-conjunct coordination. What at first glance appears to be reordering in 'adversative' exclamatives is in fact a bi-sentential sequence, where only the second sentence is exclamative.

We may wonder why a bi-sentential structure like (43b) is not available as an alternative to (41), as the ungrammaticality of (43a) shows. My tentative answer is that the 'concessive' import of (41) requires a single (complex) sentence, specifically a two-conjuncts coordinate structure, similarly to other cases of «semantic subordination despite syntactic coordination» (Culicover and Jackendoff 1997). An alternative to (43a) with subject-verb inversion in the initial sentence (i.e. não apareceu ela) would be ungrammatical as well. This indicates that coordination is a central piece in the construction of the exclamative sentences we are discussing, so that each conjunct alone cannot constitute an exclamative utterance. Again being tentative, I would suggest that the feature evaluative requires not only phonological visibility (cf. Roberts 2001, Martins 2013), thus triggering movement, but must additionally be under the scope of an appropriate operator, which in coordination exclamatives is the coordinator itself, acting as an operator of comparison/contrast. 
(43) a. *Ela não apareceu(;) e convidei-a eu para jantar! she not appeared and invited-her I for dinner

b. Está um dia de sol(;) [ CoP $_{\text {e }}$ não fomos nós ao jardim zoológico!] is a day of sun (;) and not went we to-the garden zoological 'It's a sunny day after all. And we ended up not going to the zoo!'

(Implied: We should have gone!)

(44) [Situation: the day began rainy but became dry and sunny]

E não fomos nós ao jardim zoológico!

and not went we to-the garden zoological

'I can't believe we did not go to the zoo!'

An intriguing question about Type II exclamatives is the exclusion of the conjunction mas 'but' as the coordinator. In fact only $e$ 'and' is allowed in Type II exclamatives (see 45a,-b). This is somehow unexpected because 'but' would contribute exactly the counterexpectational import that is characteristic of the inter-propositional relation of Type II exclamatives (see the contrasts between $(45 \mathrm{a}) /(45 \mathrm{c}) /(45 \mathrm{~d}))$. The answer to the puzzle is possibly to be found in the discourse-informational properties of 'but'. The adversative conjunction appears to always introduce salient information in the discourse (cf. Umbach 2005). As discussed in section 2, exclamatives do not provide information but instead express a speaker's attitude towards a presupposed/non-controversial content. Hence we have a motivation for the exclusion of mas 'but' from coordination-based exclamatives. ${ }^{17}$

17. The word mas 'but' can precede the wh-phrase of wh-exclamatives but is excluded when there is no wh-phrase (see (i) below). In this respect, it behaves likes interjections (see (ii) below). I take mas in (ia) to be an emphatic marker, or an intensifier, like in (iii), not a coordinate conjunction.

(i) a. (Ai) (mas) que linda casa o João comprou! INTERJ but what beautiful house the João bought 'What a beautiful apartment João has bought!'

b. Linda casa o João comprou! beautiful house the João bought 'What a beautiful apartment João has bought!'

c. *Mas linda casa o João comprou! but beautiful house the João bought

(ii) a. Ai que linda casa!

INTERJ what beautiful house

b. *Ai linda casa!

INTERJ beautiful house

'What a beautiful apartment!'

(iii) a. É feio, mas feio! is ugly but ugly

b. Bolas é feio mas feio! INTERJ is ugly but ugly

c. *Bolas é feio! INTERJ is ugly

'How ugly it is!' 
(45) a. Ofereci-lhe eu um iPhone e ele não me telefona! offered-him I an iPhone and he not me calls 'Although I gave him an iPhone, he does not call me!'

(Implied: He should call me! or I shouldn't have bought him the iPhone!)

b. *Ofereci-lhe eu um iPhone mas ele não me telefona! offered-him I an iPhone but he not me calls

c. \#Ofereci-lhe eu um iPhone e ele (agora) telefona-me! offered-him I an iPhone and he now calls-me

d. Eu ofereci-lhe um iPhone e ele (agora) telefona-me. I offered-him an iPhone and he now calls-me 'I gave him an iPhone and he now (after all/finally) calls me.'

The two sentences in (46) below are both grammatical but while the former is a declarative introducing new information, the latter is an exclamative commenting on presupposed information. Adding a because-clause (see (47)) or a modal verb (see 48)) in the second conjunct is fine with the declarative sentence (the (a) examples) but unfelicitous with the exclamative sentence (the (b) examples).

(46) a. Eu convidei-a para jantar mas ela não apareceu.

I invited-her for dinner but she not appeared

'I invited her for dinner but she didn't come.'

b. Convidei-a eu para jantar e ela não apareceu! invited-her I for dinner and she not appeared 'I invited her for dinner and she didn't show up!' / 'Although I invited her for dinner, she didn't show up!'

(Implied: She should have shown up! or I shouldn't have invited her!)

(47) a. Eu convidei-a para jantar mas ela não apareceu porque o filho I invited-her for dinner but she not appeared because the son foi hospitalizado.

was hospitalized

'I invited her for dinner but she didn't come because her son was hospitalized.'

b. \#Convidei-a eu para jantar $e$ ela não apareceu porque o invited-her I for dinner and she not appeared because the filho foi hospitalizado!

son was hospitalized

(48) a. Eu convidei-a para jantar mas ela não pode vir.

I invited-her for dinner but she not could come

'I invited her for dinner but she couldn't come.'

b. \#Convidei-a eu para jantar e ela não pode vir! invited-her I for dinner and she not could come 
Valadas (2012) uncovered an interesting (semantic) equivalence between coordinate and subordinate structures relative to Type II exclamatives. While 'concessive' exclamatives can be expressed by coordination with $e$ or subordination with para 'for' (and convey an unwilled/unexpected result relation), 'adversative' exclamatives can be expressed by coordination with $e$ or subordination with quando 'when' (and convey an infelicitous/unexpected time-coincidence relation). This is illustrated in (49) and (50), respectively.

(49) a. Leu o miúdo os livros todos $e$ o professor deu-lhe esta read the kid the books all and the professor gave-him this nota! grade

b. Leu o miúdo os livros todos para o professor lhe dar esta read the kid the books all for the professor him give this nota! grade

'Although the kid read everything, the teacher gave him this (low) grade!' (Implied: The teacher should have given the kid a better grade! or There was no need for reading everything after all!)

(50) a. Convidei eu toda a gente para jantar $e$ afinal ainda não invited I all the people for dinner and after all yet not recebi o ordenado! received the salary

b. Convidei eu toda a gente para jantar quando afinal ainda não invited I all the people for dinner when after all yet not recebi o ordenado!

received the salary

'I invited everybody for dinner and/but after all I haven't received my salary yet!'

(Implied: I shouldn't have invited everybody for dinner!)

The different subordinate clauses displayed by the (b) examples lend support to the proposed distinction between the two variants of Type II exclamatives. When a subordinate structure conveys the semantic import of Type II exclamatives there is presumably one single evaluative feature associated with the matrix $\mathrm{C}$ that takes scope over the whole sentence. In this case, it is the subordinative connector itself that contributes the particular semantics of each variant of Type II exclamatives. ${ }^{18}$ Fronting of

18. In the variant that I have coined as 'concessive' an expected result relation is contradicted (if I invite a friend for dinner, the expected result is that she shows up for dinner; if the kid reads all the books, the expected result is that he will not get a bad grade, and so on). No such result relation arises in the sentences that I have coined as 'adversative' (the fact that I invite people for dinner does not have as expected result that I am paid my salary on time, nor the weather conditions are expected to be influenced by my decisions about going to the zoo). 
the subordinate clause is blocked in both cases, as exemplified in (51)-(52), although subordinate clauses with para and quando can usually be fronted (compare the $(\mathrm{a} / \mathrm{b})$ declaratives with the (c/d) exclamatives). This has its parallel in the fixed order of the conjuncts in the corresponding coordinate structures (remember that apparent reordering in Type II 'adversatives' is in fact single-conjunct coordination).

(51) a. Eu fiz peixe para o jantar para ele comer. I did fish for the dinner for he eat 'I cooked fish for dinner, so he would eat.'

b. Para ele comer, eu fiz peixe para o jantar.

c. Fiz eu peixe para o jantar para ele não comer! did I fish for the dinner for he not eat 'I cooked fish for dinner and he did not eat!'

(Implied: He should have eaten! or I shouldn't have bothered cooking fish for him!)

d. *Para ele não comer fiz eu peixe para o jantar!

(52) a. Eu fiz o jantar quando ele quis comer.

I did the dinner when he wanted eat

'I cooked dinner as soon as he wanted to eat.'

b. Quando ele quis comer, eu fiz o jantar.

c. Fiz eu o jantar quando ele já tinha comido!

did I the dinner when he already has eaten

'I cooked dinner and after all he had already eaten!'

(Implied: I shouldn't have cooked dinner)

d. *Quando ele já tinha comido fiz eu o jantar!

Subordination structures with para make particularly evident the contrast between SVO declarative sentences and VSO exclamative sentences. The evaluative feature of the latter induces $\mathrm{V}$-to-C in the root domain, deriving verb-subject inversion and the particular interpretation of exclamatives. This is exemplified by (53)-(54).

(53) a. Ofereci-lhe eu um iPhone para ele não me telefonar!

VSO exclamative

offered-him I an iPhone for he not me call

Lit. 'I gave him an iPhone for him not to call me!' (ironic reading)

'Although I gave him an iPhone, he does not call me!'

(Implied: It wasn't for this (i.e. not calling me) that I gave him an iPhone!

/ He should call me! / I shouldn't have given him an iPhone!)

b. \#Eu ofereci-lhe um iPhone para ele não me telefonar. SVO declarative

I bought-him an iPhone for he not me call

'I bought him an iPhone for him not to call me.' 
(54) a. \#Ofereci-lhe eu um iPhone para ele me telefonar! VSO exclamative offered-him I a iPhone for he me call (no available interpretation)

b. Eu ofereci-lhe um iPhone para ele me telefonar. SVO declarative I bought-him a iPhone for he me call

'I bought him a iPhone for him to call me.'

There is no counterexpectational ingredient in (54) and this makes the exclamative sentence unavailable. In (53) the evaluative feature of the exclamative sentence brings up an ironic reading that is not available for the declarative sentence and therefore cannot make sense of it.

\section{Conclusion (VSO, coordination and exclamatives)}

This paper investigates two types of non-degree exclamatives that reveal an interesting interaction with coordination. Coordination provides a configuration for comparison/contrast between two propositions and so makes explicit the unexpectedness relation that supports the speaker's emotive reaction in non-degree exclamatives. Coordination also provides a mechanism of feature percolation that gives a syntactic basis to the evaluative component of the exclamative constructions.

It is proposed here that the presence of an evaluative feature in $\mathrm{C}$ is a common feature of different types of exclamatives. Syntactically, it may be licensed in different ways and by different elements, which is compatible with the well known diverse syntactic formats of exclamatives. In the two types of exclamatives discussed in the paper the $\mathrm{C}$-based evaluative feature drives verb movement to $\mathrm{C}$, originating the VSO word order.

While sharing the coordination configuration and subject-verb inversion, the two types of non-degree exclamatives diverge in some traits, for which the analysis proposed in the paper seeks to offer an integrated account. The interaction between properties of coordination structures (Johannessen 1998) and the distribution and requirements of the evaluative feature of exclamatives offer the basis for understanding why there are differences relative to constituent order symmetry or the availability of single-conjunct coordination (though much is left for further inquiry). Besides, the subject DP left behind by verb movement may stay inside IP (Type II exclamatives) or move to a low FocP position in the CP field (Type I exclamatives) and therefore exhibit a contrastive focus interpretation.

The proposals put forth in this paper to account for the two types of non-degree exclamatives may prove useful in future work to understand other instances of the marked VSO order in European Portuguese, and potentially other languages. ${ }^{19}$

19. The evaluative feature of exclamatives is presumably behind the VSO order of sentences like (i) below, and maybe (ii) as well. The availability of the low FocP position explains the VSO order of the declarative sentences in (iii), taken from email messages (cf. Culicover and Winkler 2008). The prompting effect of coordination is clear in (iiia). In (iiib) coordination is implicit ('if it is you (not me) who is with her first'). 


\section{References}

Ambar, Manuela (1992). Para uma sintaxe da inversão sujeito-verbo em português. Lisboa: Colibri.

Ambar, Manuela 1(1999). «Aspects of the syntax of focus in Portuguese». In: Rebuschi, George; Tuller, Laurice (eds.). The grammar of focus. Amsterdam/Philadelphia: John Benjamins, pp. 23-53.

Andueza, Patricia (2011). Rhetorical exclamatives in Spanish. The Ohio State University, doctoral dissertation.

Batllori, Montserrat; Hernanz, Maria-Lluïsa (2013). «Emphatic polarity in Spanish and Catalan». Lingua 128: 9-30.

Camacho, José (2003). The structure of coordination: Conjunction and agreement phenomena in Spanish and other languages. Dordrecht: Kluwer Academic Publishers.

Castroviejo Miró, Elena (2008). «Deconstructing exclamations». Catalan Journal of Linguistics 7: 41-90.

Costa, João (1998). Word Order Variation: A constraint-based approach. The Hague: Holland Academic Graphics.

Costa, João; Martins, Ana Maria (2011). «On focus movement in European Portuguese». Probus 23.2: 217-245.

Culicover, Peter; Jackendoff, Ray (1997). «Semantic subordination despite syntactic coordination». Linguistic Inquiry 28.2: 195-217.

Culicover, Peter; Winkler, Susann (2008). «English focus inversion». Journal of Linguistics 44.3: 625-658.

González Rodríguez, Raquel (2008). «Exclamative wh-phrases as positive polarity items». Catalan Journal of Linguistics 7: 91-116.

Grimshaw, Jane (1979). «Complement selection and the lexicon». Linguistic Inquiry 10.2: 279-326.

Gutiérrez-Rexach, Javier (1996). «The semantics of exclamatives». In: Garrett, Edward; Lee, Felicia (eds.). Syntax at Sunset. UCLA Working Papers in Linguistics.

(i) Desse-me ele presuntos em vez de rezas!

give-me he hams in turn of prayers

'If he would give me provisions instead of prayers!'

(ii) Fizeste tu bem!

did you well

'You did well!' (against what people may say/think)

(iii) a. Amanhã escrevo aos organizadores. Há uns tempos ficaram de me dizer tomorrow write-1SG to the organizers there is some time stayed of me tell se comprava eu o bilhete ou compravam eles.

if bought I the ticket or bought them

'Tomorrow I will write to the conference organizers. They were supposed to let me know whether I will buy the ticket or they will.'

b. Na próxima quarta vou ao Centro e pode ser que ela esteja lá. in-the next Wednesday go.1sG to-the Center and could be that she is there Mas se acontecer estares tu com ela primeiro, também podes falar-lhe (tu) but if happens be you with her first also can.2sG speak-her you no assunto.

in-the matter

'Next Wednesday I will be in the Center and maybe I will meet her there. But if it happens that you are with her first, then you can talk to her yourself about this matter.' 
Gutiérrez-Rexach, Javier; Andueza, Patricia (2011). «Degree restriction in Spanish exclamatives». In: Ortiz-López, Luis A. (ed.). Selected Proceedings of the 13th Hispanic Linguistics Symposium. Sommerville, MA: Cascadilla Press, pp. 286-295.

Hernanz, Maria-Lluïsa (2010). «Assertive Bien in Spanish and the left periphery». In: Paola Benincà; Munaro, Nicola (eds.). Mapping the left periphery. Oxford: OUP, pp. 19-62.

Johannessen, Janne Bondi (1998). Coordination. Oxford: OUP.

Martins, Ana Maria (2013). «Emphatic Polarity in European Portuguese and Beyond». Lingua 128: 95-123.

Martins, Ana Maria (forthcoming). «How much syntax is there in metalinguistic negation?». Natural Language and Linguistic Theory.

Melvold, Janis (1991). «Factivity and definiteness». In: Cheng, Lisa; Demirdache, Hamida (eds.). More papers on wh-movement. MIT Working Papers in Linguistics 15.

Ono, Hajime (2006). An investigation of exclamatives in English and Japanese: Syntax and sentence processing. University of Maryland at College Park, doctoral dissertation.

Portner, Paul; Zanuttini, Raffaella (2000). «The force of negation in wh-exclamatives and interrogatives». In: Horn, Laurence R.; Kato, Yasuhiko (eds.). Negation and polarity: Syntactic and semantic perspectives. Oxford /New York: OUP, pp. 193-231.

Progovac, Liiljana (1998a,b). «Structure for coordination Part I / Structure for coordination Part II». Glot International Volume 3, Issue 7-8, September 1998/October 1998.

Raposo, Eduardo (1995). «Próclise, ênclise e posição do verbo em português europeu». In: Camilo dos Santos, João; Williams and Frederick G. (eds) O amor das letras e das gentes: In honor of Maria de Lourdes Belchior Pontes. Santa Barbara: Center for Portuguese Studies - University of California, pp. 455-481.

Raposo, Eduardo (2000). «Clitic positions and verb movement». In: Costa, João (ed.). Portuguese syntax. New comparative studies. Oxford/New York: OUP, pp. 266-297.

Rett, Jessica (2008). Degree modification in natural language. New Brunswick Rutgers - The State University of New Jersey, doctoral dissertation.

Roberts, Ian (2001). «Language change and learnability». Bertolo, Stefano (ed.). Language Acquisition and Learnability. Cambridge: CUP, pp. 81-125.

Umbach, Carla (2005). «Contrast and information structure: A focus-based analysis of but». Linguistics. 43.1: 207-232.

Valadas, Ana Rita (2012). A inversão sujeito-verbo em frases declarativas exclamativas do português. Faculdade de Letras da Universidade de Lisboa, Trabalho final do Seminário de 'Linguística Comparada: Tópicos de Gramática do Português' (Mestrado em Linguística 2011-2012).

Villalba, Xavier (2004). «Exclamatives and negation» (Technical Research Report GGT-2004-02). Bellaterra: Grup de Gramàtica Teòrica, Universitat Autònoma de Barcelona.

Villalba, Xavier (2008). «Exclamatives: a thematic guide with many questions and few answers». Catalan Journal of Linguistics 7: 9-40.

Zamparelli, Roberto (2011). «Coordination». In: von Heusinger, Klaus; Maienborn, Claudia; Portner, Paul (eds.). Semantics: An international handbook of natural language meaning. Berlin: Mouton de Gruyter, pp. 1713-1741.

Zanuttini, Raffaella; Portner, Paul (2003). «Exclamative clauses: at the syntax-semantics interface». Language 79.1: 39-81. 
